\title{
Original article \\ URINARY SCHISTOSOMIASIS AND CONCOMITANT URINARY TRACT PATHOGENS AMONG SCHOOL CHILDREN IN METROPOLITAN IBADAN, NIGERIA
}

\author{
ADEYEBA, O. A. AND* OJEAGA, S.G.T. \\ ${ }^{1}$ Department of Medical Microbiology and Parasitology, College of Health Sciences, Ladoke Akintola \\ University of Technology, Ogbomoso; ${ }^{2}$ Department of Medical Microbiology, University College Hospital, \\ Ibadan, Nigeria.
}

\begin{abstract}
This study on the prevalence of urinary schistosomiasis and concomitant urinary tract pathogens was carried out between August and December, 1998, among school children in Ibadan North Local Government Area. Terminal urine sample collected from only pupils in classes 3 to 6 for the study were analyzed accordingly using the methods as described. Of the 1600 pupils examined, 920 (57.5\%) who had the ova of Schistosoma haematobium also had pyuria; $75.4 \%$ of which had concomitant bacteriuria. There was no significant difference in the distribution of schistosomasis among sexes as against age influence. Symptoms of haematuria are not pathognomonic of the infection. Result shows that there is a linear relationship between scream water contact/ usage and infection rate. The bacteriuria isolated included Klebsiella sp.; Escherichia coli, Staphylococcus aureus with Esch. Coli occurring more frequently than the rest. The antibiogram of the isolates revealed that Tarivid and perfloxacin were the most effective drugs in case management of concomitant bacteriuria among the school children. The components of control of urinary schistosomisasis are highlighter. The integration of complementary strategies would lead to a great success in control effort.
\end{abstract}

Key Words: Urinary Schistosomiasis, Concomitant bacteriuria, School children, Stream, Ibadan.

\section{INTRODUCTION}

Microbial invasion being the basis of urinary tract infection could be seen in various clinical manifestations resulting into various disease conditions in both males and females. These disease conditions include pyelonephritis which was shown to be non-age discriminatory as it affects both older person and infants with age range of 2 weeks to 18 years (Rushton and Majd, 1995). The children at great risk for kidney damage are intants and young children of school age with febrile urinary tract infection in whom effective but are more oftern than not asymptomatic and frequently recurrent (Kunin, 1971; 1979).

Although, urinary schistosomiasis is endemic in Nigeria, it is usually a neglected common parasitic disease of childhood (Adewumi et al, 1991; Bello and Edungbola, 1992). Also no attempt has been made in recent past to report the secondary urinary tract pathogen, that could be associated with the disease among school age children in the country, especially south west Nigeria.

There is therefore an urgent need for a renewed commitment to control schistosomiasis and concurrent bacteriuria among the school age group in the country. Hence, this study is designed to determine the prevalence of schistosomiasis and secondary urinary tract infection aetiologic agents among school children in Ibadan metropolis with a view to producing a database for effective control plan.

\section{MATERIALS AND METHODS}

\section{Study Area and Sample Collection}

This study was carried out among elementary school elementary school children in Ibadan metropolis, Nigeria. There is a bias for schools situated near streams in Ibadan. Hence, for the purpose of this study all schools located near streams in Ibadan were considered 
and two were selected by balloting. Saint John RCM primary School, Inalende located near Dandaru stream, Mokola, and Adelagun Primary School near Aperin Stream at Orita Apein, Ibadan were thus selected.

The two schools were visited for the purpose of sample collection once in a week between August and December, 1998. The pupils in primary 3-6 were selected as study population according to the recommendation of Arionla (1991) since pupils in lower classes are usually under aged and would be difficult to manage. All the subjects in study population were assigned for sample collection with the active support of staff and students of the two schools. Terminal urine samples were collected into clean sterile universal bottles from 1600 subjects from the two schools. 795 from St. John's school and 805 from Adelagun school respectively. Prior to the collection of samples the pupils were to undergo physical exercises at around noon time (12.00) and 1400)hr) as recommended by Piekarski (1989). The information on age, sex duration of stay in school, stream water usage and symptoms of infection was taken from each subject.

\section{Sample Analysis}

Diagnosis by microscopy as described by Piekarski (1989) was employed. About $10 \mathrm{ml}$ terninal urine was centrifuged at $2000 \mathrm{rpm}$ for 3 minutes in order to concentrate egg of the schistosome.The deposit was examined microscopically using the $x 40$ objectives for the characteristic eggs as described by Muller (Muller, 1975) and Piekarski (1989) pus cells and red blood cells in samples were noted.

All the pyuric samples that contained schistosome eggs were cultured on Blood agar and CLED agar plates respectively. Using the method described by Colle et al (1989). All bacterial isolates thus obtained were characterised by using the standard methods described by Cowan and Steel (1975). The control organisms used were standard Escherichia coli (NCTC 10418) and Oxford staphylocccus (NCTC 6571).

Antibiogram of isolates was done using the dise agar diffusion method described by Stokes (1968). The following antibiotics were employed: tarivid, perfloxacin. Rocephine, ceftercidine Gentamycin, Colistin, Amoxylin, Tetracycline, Cotrimoxazole, Nalidixic acid and streptomycin.

\section{Data Analysis:}

The data analysis was done using $x^{2}$ (chi- square ) test to determine significant relationship between the variables.

\section{RESULTS}

Distribution of urinary schistosomiasis by age and sex is presented in Table 1. Result shows that generally more males than females were infected with $S$. haematobium $(p<0.05)$. Although there was no definite linear relationship between age progression and infection rate, subjects in the age 16 years and above cohort had the least infection rate of $32 \%$ while those in $10-12$ years age bracket had the highest infection rate of $70.1 \%$. Data revealed that the entire $57.5 \%$ that has S. haematobium also had pyuria.

Distribution of schistosomiasis by stream water usage and symptomatology is shown in Table 2. Data revealed that there is no significant relationship between the symptoms and infection distribution using the $x^{2}$ test

$(p, 0.05)$. Result shows that stream water contact has linear relationship with infection rate.

Table 3 shows the prevalence of concomitant bacteriuria in school children infected with $S$. haematobium by sex. Statistical analysis by $x^{2}$ test revealed that there is no significant difference the sexes and also the bacteriuria distributions since the calculated value $\mathrm{t}$ (13.15) is greater than tabulated $t$ value (12.59) $\quad(p>0.05)$. Any perceived difference is due to mere chance. 
African Journal of Biomedical Research (2002): Vol. 5 / Adeyeba and Ojeaga

Table 1:

Prevalence Of Urinary Schistosomiasis Among School Children In Ibadan By Age And Sex

\begin{tabular}{llllllll}
\hline $\begin{array}{l}\text { Age } \\
\text { Group } \\
\text { (Year) }\end{array}$ & Male & \multicolumn{7}{c}{ Female } & & Male \\
\hline & No & No Infected & \% Infected & No Examined & No Infected & \% Infected & No Examined \\
& Examined & & & & & \\
\hline$<10$ & 198 & 120 & 60.6 & 184 & 105 & 57.1 & 382 \\
\hline $10-12$ & 420 & 328 & 78.1 & 196 & 104 & 53.1 & 54.9 \\
\hline $13-15$ & 280 & 125 & 55.6 & 272 & 122 & 52.1 & 50 \\
\hline$>16$ & 22 & 7 & 31.8 & 28 & 9 & 50 & 1600 \\
\hline Total & 920 & 580 & 630 & 680 & 340 & 50 \\
\hline
\end{tabular}

* The whole 920 subjects were pyuric

Table 2:

Distribution of urinary Schitosomiasis By Stream Water Usage and Symptoms

\begin{tabular}{llcccccc}
\hline SYMPTOMS/ WATER USAGE & \multicolumn{2}{l}{ MALE NO=580 } & \multicolumn{2}{l}{ FEMALE NO $=\mathbf{3 4 0}$} & \multicolumn{2}{l}{ MALE + FEMALE N=920 } \\
\hline & NO POSITIVE & $\%$ & NO POSITIVE & $\%$ & NO. POSITIVE & $\%$ \\
\hline Haematuria & 406 & 70 & 238 & 70 & 644 & 70 \\
\hline No Haematuria & 174 & 30 & 102 & 30 & 276 & 70 \\
\hline Painful Urination & 397 & 68.4 & 297 & 87.4 & 694 & 77 \\
\hline Swimming in Stream & 573 & 98.8 & 135 & 39.7 & 708 & 99.0 \\
\hline Fetching Stream Water & 571 & 98.4 & 340 & 100 & 911 & 98.9 \\
\hline Washing in Stream & 570 & 98.31 & 340 & 100 & 910 & 77 \\
\hline
\end{tabular}

Table 3;

Urinary Tract Pathogens Secondary To Urinary Schistosomiasis Among School Children By Sex

\begin{tabular}{llll}
\hline BACTERIA AGENTS & Male No=580 & Female No $=\mathbf{3 4 0}$ & Total Male-
\end{tabular}

\begin{tabular}{llllll} 
& No Positve & \% Positve & No Positive & \% Positive & No Positve \\
\hline Klebsiella Species & 103 & 17.8 & 97 & 28.5 & 200 \\
\hline Eschericha coli & 131 & 22.6 & 30.9 & 30.9 & 236 \\
\hline Staphylococus aureus & 96 & 16.6 & 66 & 19.4 & 162 \\
\hline Protein Species & 53 & 9.1 & 27 & 7.9 & 80 \\
\hline Pseudomonas species & 14 & 2.4 & 2 & 0.6 & 16 \\
\hline TOTAL & 397 & 64.4 & 297 & 84.7 & 694 \\
\hline
\end{tabular}

Table 4.

Antibiotic Susceptibility Pattern of Bacterial Isolates

\begin{tabular}{lccccc}
\hline \multicolumn{1}{c}{ Antibacterial Agents } & \multicolumn{5}{c}{ Percentage Sensitivity } \\
\hline & Pseudo Spp & Klebsiella Spp & E.Coli & Staph. aureus & Proteus \\
\hline Tarivid & 89 & 85 & 50 & 100 & 100 \\
\hline Perfloxacin & 100 & 61.7 & 90.2 & 82.1 & 100 \\
\hline Rocephine & 80.4 & 61.7 & 43.9 & 82.1 & 100 \\
\hline Ceftercidine & 89 & 68.3 & 70 & 50 & 17.9 \\
\hline Gentamycin & 69.6 & 70 & 70 & 64.3 & 55 \\
\hline Colistin & 10.9 & 70 & 43.9 & 100 & 25 \\
\hline Amoxycilin & 0 & 23.3 & 12.2 & 16.5 & 70 \\
\hline Tetracycline & 0 & 0 & 0 & 64.3 & 5 \\
\hline Cotrimoxazole & 0 & 23.3 & 0 & $17 / 9$ & 0 \\
\hline Nalidixic acid & 0 & 0 & 0 & 64.3 & 25 \\
\hline Streptomycin & 0 & 0 & 0 & & 0 \\
\hline
\end{tabular}


Antibiogram of bacterial isolates as shown in Table 4 revealed that Tarivid and perfloxaxin are mostly effective against most urinary. Tract pathogens.

\section{DISCUSSION}

In the 1950s, widespread optimism prevailed amongst those working in the field of public health that tropical diseases including schistosomiasis would soon be things of the past. Indeed, some were already considered to be part of history and it was expected that economic development would overcome any existing one. The global problem of tropical diseases however has grown tremendously over the last decades despite much action from all quarters including W.H.O (1997).

The magnitude of the problem posed by schistosomiasis is very high in Nigeria especially among school children. This study has shown that $57.5 \%$ of school children in Ibadan are infected with Schistosoma haematobium. Adewumi et al (1991) also reported higher prevalence rate of $66.4 \%, 76.2 \%$ respectively in three contiguous communities in SouthWest Nigeria. Similarly, many other workers $(5,13)$; recorded a very high prevalence rate in Kwara state, Nigeria.

Generally, more males than females wee infected with $S$. haematobium $(p<0.05)$ in this study. This finding could be explained away considering the fact that boys are very active. The interaction with stream water appears more in males than female students. The boys often engage in unbridled swimming play especially after school hours (fig. 1). This practice exposes the boys more to risk of infection since the level of exposure or contact with stream eater containing cercariae of parasite and the risk of infection are linearly related. Although the female could engage in water fetching and washing beside stream in the company of their parents or guardians. Their exposure in not as that of the boys who may also assist in fetching water. The problem of shortage of potable water supply in Ibadan is major and yet Government is only paying lips service to the solution to the problem. This has aggravated the problem of schistosomiasis and other water Borden diseases in the area. That school children within 10-12 years cohort had that highest prevalence active and adventurous. Subjects in this age group were seen to be engaged in activities, which necessitate more contact with steam water. (fig 1). These children sometimes urinate or even defaecate into the steam thereby "propagating" the infection. This observation was also made by some authors (Bello and Edungbola, 1992) in Kwara State, Nigeria.

Although, symptoms are often indicators of infection in some cases, diagnosis based mainly on visible blood in urine of patients can not be said to be pathognomonic of schistosomisis as only $30 \%$ cases of infected sub jects had haematuria.

This study revealed that 920 of 1600 (57.5\%) of subjects examined had pus cells in their urine. This finding is suggestive of inflammatory lesion on the bladder caused by $S$. haematobium. Eggs deposition in the tissue could give rise to inflammation and granuloma formation leading to subsequent urinary tract infection. It has been observed that only subjects with schistosomiasis had pyuria. Earlier on some authors had implicated pyuria with bacterial infection (Bhatt et al). This explains the selection of the 920 samples for bacteriological assessment in this study.

Some authors had implicated Esherichia coli, (Kaye, 1972; Gordon and Stuart, 1989; Walter et al, 1989; Neu, 1992; Roohalla and Stacy, 1995). The report that Esch coli is the most frequently encountered urinary tract pathogen (Kaye, 1972) is a confirmation of our findings. This is closely followed in revalence by klebsiella species among subjects primariljy infected with urinary schistosomiasis is Pseudomonas species. In all, $75.4 \%$ of subjects with the primary infection had one bacteriuria or the other.

Some of those infected did not present with any symptom such as painful micturition. This development poses a great danger to the health of the school children who have come into term with 
the asymptomatic infection probably due to chronic nature of the infection. The health implication on the children is better inagined than experienced. Hence the need for mass treatment of the children is more urgent than before. Where it is not economically feasible to bacteriologically screen individual subjects in an area, urine microscopy could be carried ouut to exclude pyuria. This indicator to bacterial infection could serve as a guide for blind treatment with Tarivid and Perfloxacin as reported in this study.

For most endemic countries the control of schistosomisais has been a challenging task. Despite considerable progress in pharmacology, epidemiology and clinical research coupled with concerted control efforts in the last decades, schistosomiasis remains a major public health concern in Nigeria. Rather than pay lips service to the control of the disease government must show consistently both political will and commitment to the implementation of a concerted strategy. For mortality. Morbidity and transmission due to schistosomiasis to be effectively controlled. There is a need for guidance by such agency as WHO Division of control of Tropical Diseases.

The component of control includes population-based chemotherapy in these areas of high schistosomiasis prevalence, the provision of safe and adequate water supplies cum sanitation. Therefore, great success would be achieved through the integration of complementary strategies such as disease surveillance, chemotherapy, health education. Water supply and sanitation in the study area and the country at large.

\section{REFERENCES}

Adewumi, G.O.. Furu. P. Christensen, N.O. Olorunmola F. (1991): Endemicity, seasonality and focality of transmission of Human schistosomiasis in three communities in South- Western Nigeria. Trop. Med. Parasitology: 42 (4): 332-334.

Arinola, T.G(1991): immunological Paramenters and Partial Characterisation of serum sulastance enhancing the inhibition of leucocyte migration in Nigeria school children with urinary schistosomiasis, Ph.D thesis, University of Ibadan, Ngeria

Bello, A.B. and Edungbola, L.D(1992): Schistosoma haematobium A neglected common parasitic disease in childhood in nigeria. Incidence and intensity of infection. Acta Paediatr 1 (8) 601-604.

Bhatt, K.M.. Bhatt S.N.. Kanja C. and Ryobe J (1984).: urinary leucocytes In bladder schistosomiasis. E. Afr. Med. J. 61 (6): 442-452.

Colle, J. G. Duguid, J.P. Fraser, A.G. and Armion B.J.(1989): In “ Practical Medical Microbiology" Vol. $213^{\text {th }}$ Ed. Churchil Licingstone p.141-160.

Cowan S.T. and Steel J.L (1975): In “ Manual for the Identification of Medical Bacteria" $2^{\text {nd }}$ Ed. Cambridge university Press 1975 P.45 114.

Edungbola L.D. Asolu S.O.. Omonisi M.K. and Ayedun B.A (1998). Schistosoma haematobium intection among school children in the Babana district, Kwara State. Afr. J. Med. Med. Sci. 17.187-193.

Gordon R.L and Stuart L (1989): Diagnosis and treatment of urinary tract infection. AM. J. Med. 1989: 100 (64): 71.

Kaye D.( 1972): Urinary tract infection J. Inf. Dis. 1972: (PT. II): 582-583

Kunin C.M (1972): Epidemiology and natural history of urinary infection in school age children. Paediatric Clin. N. Am: 1971 18: 509-528

Kunin C.M. (1979): In detection. Prevention and mangement of urinary tract infection in school children. An epidemiologic, clinical and laboratory study. Med. - 43: 91-30.

Muller R. (1975): In "Worms and Dieases. A manual of Medical Helminthology", Heinemann. P.68-85.

Neu H.C (1992): Urinary tract infection AM J. Med. 1992. 92 (4) : 63-70

Piekarski G. (1989): In "Medical Parasitology “ Springer- Verlag Berlin Berlin Heidelberg 1989p. 168-169.

Roohalla SRG. and Stacy C (1995): Treatment of Urinary tract Infection AM..J. Med. 1995: 100 (6A): 171.

Rushton H.G. and Majd M (1995): Pyelonephritis in male infant: How imortant is foreskin? J. Urol 1995148 (2pt 2): 733-736.

Stokes. EJ (1968).: In" Clinical Bacteriology" $3^{\text {rd }}$ Ed. London Edward Arnold 1968.

Walter E.S. (1989): Thomas. M.H.: James. R.J. Carolyn J.Ann S. pacita L. R. Steve L.M.J. Med. 1989: 100" (64): 71.

World health Organisation: (1998): 1997Progress Report of Division of control of Tropical : Diseases. WHO/CTD/ PR/98.5 P.119-130. 
African Journal of Biomedical Research (2002): Vol. 5 / Adeyeba and Ojeaga 